\title{
GENETIC DIVERSITY OF ORAL Fusobacterium nucleatum ISOLATED FROM PATIENTS WITH DIFFERENT CLINICAL CONDITIONS
}

\author{
Mario J. AVILA-CAMPOS, Irma N. RIVERA \& Viviane NAKANO
}

\begin{abstract}
SUMMARY
The genetic diversity of 23 oral Fusobacterium nucleatum isolated from 15 periodontal patients, eight from seven healthy subjects, nine from nine AIDS patients and two from two Cebus apella monkeys were analyzed. EcoRI restricted the bacterial DNA and 28 ribotypes grouped from A to J groups were obtained. Isolates formed 24 ribotypes which were contained into A, B, C, $\mathrm{D}, \mathrm{E}$ and $\mathrm{F}$ groups, and three reference strains and two clinical isolates of A. actinomycetemcomitans, and E. coli CDC formed four different ribotypes into the $\mathrm{G}, \mathrm{H}, \mathrm{I}$ and $\mathrm{J}$ groups. Moreover, from nine F. nucleatum from AIDS patients, six were ribotyped as group $\mathrm{C}$ and three as group D. By using ribotyping we distinguished $F$. nucleatum recovered from different sources. It is possible that isolates from AIDS patients may contain some phenotypic or genotypic factor did not observed in this study.
\end{abstract}

KEYWORDS: Anaerobic bacteria; Periodontopathogens; Periodontal disease; Fusobacterium nucleatum; Ribotyping.

\section{INTRODUCTION}

Fusobacterium nucleatum is one of the species that is statistically related to the periodontal disease, and it is the most common anaerobe present in human clinical infections such as sinusitis, pelvic infections, osteomyelitis, and brain and lung abscesses ${ }^{5,7}$. F. nucleatum constitutes a considerable part of the subgingival microbiota of gingivitis in children and adults and of periodontitis in juveniles and adults ${ }^{13}$. However, the role of this microorganism in periodontal disease remains undefined due to the heterogeneity within the species ${ }^{3}$.

From an ecological point of view, there are few studies concerning the clonal diversity of gram-negative anaerobes indigenous to the human and the animal microbiota. Although many studies have examined the subgingival plaque microbiota by isolation, only few have characterized or subtyped $F$. nucleatum from different sources or clinical conditions. F. nucleatum has been recovered from $80 \%$ of periodontal patients and from $67.6 \%$ of healthy subjects ${ }^{8}$ and a stable colonization in edentulous children was also observed ${ }^{13}$.

The identification and the enumeration of the putative periodontal organisms from human dental biofilm samples present numerous technical difficulties due to the fastidious nature of the anaerobic bacteria ${ }^{17}$. An accurate identification of fusobacterial species is therefore very important not only for taxonomic reasons but also for the appropriate treatment of infections, since the susceptibility of different fusobacterial species to the wide variation of antibiotics ${ }^{10}$.
Despite the large knowledge about the pathogenic potential and the medical aspects of fusobacteria, their metabolic and genetic aspects are little $\mathrm{known}^{4,16}$. In the last years, the use of tools as cloning, sequencing and PCR have given more information about the genetic aspects of $F$. nucleatum. Several methods of detecting phenotypic and genotypic characteristics have been used to distinguish those bacterial pathogens from commensal strains ${ }^{6}$. Different studies have underscored the heterogeneous nature of the genus Fusobacterium particularly among isolates of $F$. nucleatum. Moreover, species and strains of Fusobacterium have been studied and compared in several ways, such as by DNA-DNA hybridization, fatty acid analysis, constitution of the peptidoglycan layer, glutamate dehydrogenase electrophoretic patterns and $\mathrm{AP}-\mathrm{PCR}^{9,11,18}$. In the present study, we have used ribotyping to examine the genetic diversity of oral $F$. nucleatum recovered from patients with different clinical conditions.

\section{MATERIALS AND METHODS}

Bacterial source: Fifteen patients with adult periodontitis (age range 18-40 years old), with clinical and radiographic evidence of the periodontal disease, including pockets of depth with equal or exceeding $5 \mathrm{~mm}$; seven healthy subjects (age range 20-30 years old); and nine AIDS patients with periodontitis (age range 25-40 years old) were selected. The male: female ratio was 9:6 (periodontal patients), 5:2 (healthy subjects) and 9:0 (AIDS patients). All the individuals were patients of the Periodontology Clinic, University of São Paulo, São Paulo, SP, Brazil. Moreover, two healthy male Cebus apella monkeys

Department of Microbiology, Institute of Biomedical Sciences, University of São Paulo, São Paulo, SP, Brazil.

Correspondence to: Dr. Mario J. Avila-Campos, Anaerobe Laboratory, Department of Microbiology, ICB, University of São Paulo, Av. Prof. Lineu Prestes 1374, 05508-900 São Paulo, SP, Brazil. Telephone: +55-11-3091-7344; Fax: +55-11-3091-7354. E-mail: mariojac@usp.br. 
from the State University of São Paulo, Araçatuba, SP, Brazil, were selected. All patients gave written informed consent to be recruited to the study and the approval was obtained from the Research Ethics Committee of the Biomedical Sciences Institute, University of São Paulo. Initially, the supragingival plaque was removed and subgingival biofilm samples were taken by using sterilized absorbent paper points (Dentsply Ind. \& Co. Ltd., Rio de Janeiro, RJ, Brazil), which were introduced into the periodontal pocket or into gingival sulcus for 60 seconds and transported in a VMGA III medium ${ }^{14}$. Aliquots of $0.1 \mathrm{~mL}$ of undiluted and $10^{-2}$ diluted samples were inoculated within two hours after collection on Omata \& Disraely agar, and incubated in anaerobic conditions $\left(90 \% \mathrm{~N}_{2} / 10 \% \mathrm{CO}_{2}\right)$, at $37{ }^{\circ} \mathrm{C}$, for four days. F. nucleatum isolates were confirmed by the following characteristics: gram-negative, non-spore forming rods, indole positive, catalase negative and asaccharolytics, and identified by conventional biochemical tests ${ }^{15,19}$. Periodontal organisms such as Actinobacillus actinomycetemcomitans isolated from periodontal patients (PD1 and PD2), $A$. actinomycetemcomitans ATCC 29522, ATCC 29523 and ATCC 43718, F. nucleatum ATCC 10953 and ATCC 25583, and Haemophilus aphrophilus $\mathrm{CDC}$ and Escherichia coli CDC (Culture collection at the Anaerobe Laboratory, Hospital Infections Program, CDC, Atlanta, GA, USA) were also included.

Extraction and restriction of the bacterial DNA: Bacteria were grown in brain heart infusion broth (BHI - Difco Laboratories, Detroit, MI, USA) supplemented with $0.5 \%$ yeast extract. Cells were harvested and lysed with sodium dodecyl sulfate (SDS) and DNA was extracted as previously described by AVILA-CAMPOS et al. ${ }^{1}$, with minor modifications. Each DNA sample was spectrophotometrically examined to determine the DNA concentration and purity. Restriction enzymes HindIII, HincII, EcoRI and EcoRV (New England Biolabs, Beverly, MA, USA) were used to digest DNA from $F$. nucleatum isolates and other bacteria to determine the most appropriate enzyme. Briefly, $1 \mu \mathrm{g}$ of DNA was digested with each enzyme in a final volume of $20 \mu \mathrm{L}$, at $37{ }^{\circ} \mathrm{C}$, during seven hours, performed according to the manufacturer's specifications. Finally, the digested DNA was run in $0.9 \%$ agarose gels. TAE (40mM Tris-acetate, 1mM EDTA, $\mathrm{pH}$ 8.0) was used as the electrophoresis buffer in a BioRad unit (20 mA, overnight). DNA molecular-weight marker II and X digoxigenin (DIG)-labeled (Boehringer Mannheim, Germany) were used as size markers.

Southern blot: Southern transfer was performed as described by BOLSTAD et $a l .{ }^{3}$. The DNA was blotted with a positively charged nylon membrane (Catalog No. 1209272; Boehringer Mannheim) recommended by the DIG-labeling method. The transfer was performed for 20 hours with $20 \mathrm{X} \mathrm{SSC}$ as the transfer buffer. All Southern blots were prehybridized at $65{ }^{\circ} \mathrm{C}$, for one hour, in hybridization buffer $(5 \mathrm{X}$ SSC [Gibco BRL], 0.5\% wt/vol blocking reagent [Boehringer Mannheim], $0.1 \% \mathrm{wt} / \mathrm{vol} \mathrm{N}$-laurosylsarcosine, $0.02 \% \mathrm{wt} / \mathrm{vol}$ SDS). The same solution was used for hybridization, and the Southern blots were hybridized with a pKK3535 plasmid DNA nonradioactive probe at $65{ }^{\circ} \mathrm{C}$, overnight. The stringent washing and the chemiluminescent detection were mainly carried out in accordance with the manufacturer's protocol for the detection of DIG-labeled nucleic acids (Genius $1 \mathrm{Kit}$, Boehringer Mannheim). The membranes were washed twice, for five minutes each one, with washing buffer ( 2 X SSC- $0.1 \%$ SDS), at room temperature and then twice, for 15 minutes each one, with $0.1 \mathrm{X}$ SSC$0.1 \%$ SDS, at $65{ }^{\circ} \mathrm{C}$. Detection was performed by incubation for two hours in diluted anti-digoxigenin-AP Fab fragments (150 U, 1:3,000) and membranes were washed twice, for two minutes, in buffer solution (100 mM Tris- $\mathrm{HCl}, 100 \mathrm{mM} \mathrm{NaCl}, 50 \mathrm{mM} \mathrm{MgCl}, 0.02 \%$ sodium azide), and incubated for 30 minutes in NBT and X-phosphate in DMF (DIG DNA labeling and detection Kit, Boehringer Mannheim) in a dark place.

Statistical analysis: Ribotypes were determined by the observation of the banding patterns, and bands were analyzed by using a NTSYS program (Applied Biostatistic, Inc Version 1.7).

\section{RESULTS}

Restriction of the DNA: In this study, HindII, HindIII and EcoRV enzymes failed to digest the DNA of all $F$. nucleatum. The EcoRI enzyme was the most efficient in cutting the bacterial DNA and in providing easily distinguishable 24 patterns among $F$. nucleatum isolates and the reference strains used, detected by using a pKK3535 probe. In addition, four more patterns were formed for the reference strains and clinical isolates of A. actinomycetemcomitans and E. coli CDC (Table 1).

Southern blot and ribotyping: Southern blots of $F$. nucleatum digested with EcoRI and hybridized with pKK3535 probe displayed similar band sizes in all the tested isolates from approximately 2.6 to $2.7 \mathrm{~kb}$ (data not shown). Moreover, F. nucleatum from AIDS patients produced additional bands ranging approximately from 7.0 to 9.0 , which were not observed in isolates from periodontal patients, healthy subjects or monkeys (Fig. 1). Isolates displaying differences in hybridization

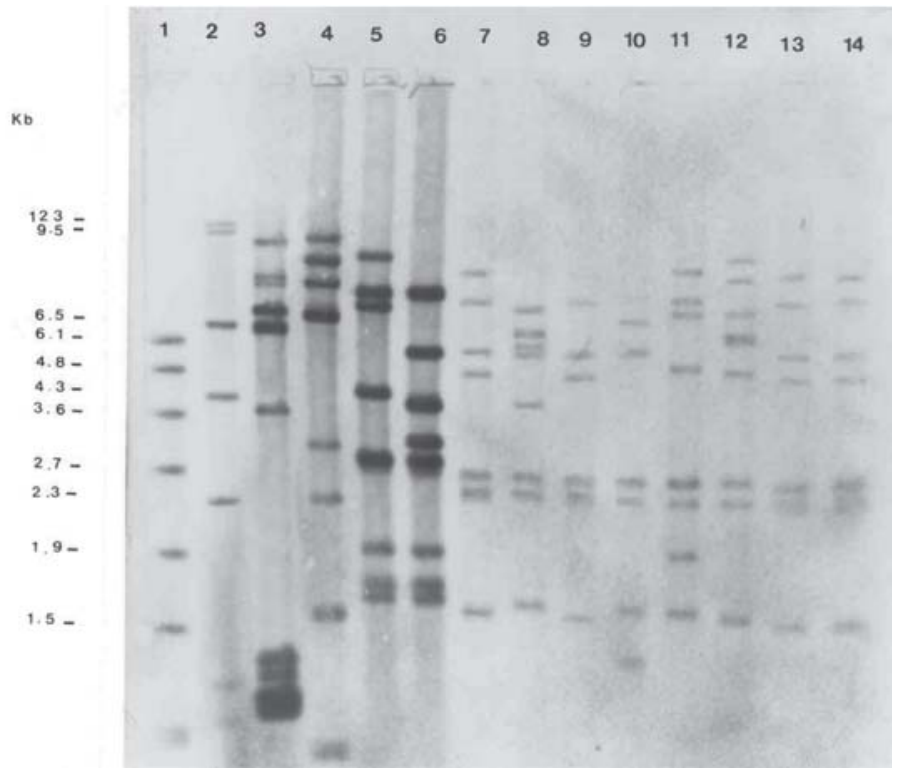

Fig. 1 - Ribotyping representative of F. nucleatum/EcoRI. Autoradiogram of Southern blot hybridized with pKK3535 probe and washed with $20 \mathrm{X} \mathrm{SSC}$ for two h, $15 \mathrm{~min}$., at $65^{\circ} \mathrm{C}$. DNA restricted with EcoRI. Lanes 1 and 2, DNA molecular weight marker (X and II, respectively); lane 3, E. coli CDC; lane 4, H. aphrophilus; lane 5, A. actinomycetemcomitans ATCC 29523; lane 6, A. actinomycetemcomitans isolated from periodontal patient; lane 7, F. nucleatum isolated from monkey; lane 8, F. nucleatum ATCC 10953; lane 9, F. nucleatum isolated from periodontal patient; lane 10, F. nucleatum isolated from healthy subject; lanes 11 and 12, F. nucleatum isolated from AIDS-patients; lanes 13 and 14, F. nucleatum isolated from periodontal patients. 
Table 1

DNA hybridization, ribotype patterns and groups of the F. nucleatum and other bacteria restricted with EcoRI

\begin{tabular}{|c|c|c|c|}
\hline Source/Isolate & Banding pattern & Ribotype (No.) & Ribotype group \\
\hline \multicolumn{4}{|l|}{ Periodontal patients (23) } \\
\hline $\mathrm{P} 10, \mathrm{P} 14, \mathrm{P} 20, \mathrm{P} 22$ & 8 & $\mathrm{Rb} 1$ & A \\
\hline P6 & 9 & $\mathrm{Rb} 2$ & $\mathrm{~B}$ \\
\hline $\mathrm{P} 1, \mathrm{P} 2, \mathrm{P} 3, \mathrm{P} 5, \mathrm{P} 15, \mathrm{P} 23$ & 8 & Rb8 & $\mathrm{D}$ \\
\hline $\mathrm{P} 11, \mathrm{P} 12$ & 10 & $\mathrm{Rb} 13$ & $\mathrm{D}$ \\
\hline P4 & 3 & $\mathrm{Rb} 14$ & $\mathrm{D}$ \\
\hline P9 & 6 & $\mathrm{Rb} 15$ & $\mathrm{D}$ \\
\hline P8 & 6 & $\mathrm{Rb} 16$ & $\mathrm{D}$ \\
\hline $\mathrm{P} 7$ & 4 & $\mathrm{Rb} 17$ & $\mathrm{D}$ \\
\hline $\mathrm{P} 13, \mathrm{P} 21$ & 4 & $\mathrm{Rb} 18$ & $\mathrm{D}$ \\
\hline P19 & 7 & Rb9 & $\mathrm{D}$ \\
\hline P16 & 7 & $\mathrm{Rb} 21$ & $\mathrm{E}$ \\
\hline P17, P18 & 8 & $\mathrm{Rb} 22$ & $\mathrm{E}$ \\
\hline \multicolumn{4}{|l|}{ AIDS-patients (9) } \\
\hline A7 & 9 & $\mathrm{Rb} 3$ & $\mathrm{C}$ \\
\hline A4 & 9 & $\mathrm{Rb} 4$ & $\mathrm{C}$ \\
\hline $\mathrm{A} 1, \mathrm{~A} 2$ & 7 & Rb5 & $\mathrm{C}$ \\
\hline A6 & 9 & Rb6 & $\mathrm{C}$ \\
\hline A5 & 8 & $\mathrm{Rb} 7$ & $\mathrm{C}$ \\
\hline $\mathrm{A} 3, \mathrm{~A} 8, \mathrm{~A} 9$ & 8 & $\mathrm{Rb} 10$ & $\mathrm{D}$ \\
\hline \multicolumn{4}{|l|}{ Healthy individuals (8) } \\
\hline $\mathrm{H} 2, \mathrm{H} 3, \mathrm{H} 4$ & 8 & $\mathrm{Rb} 8$ & $\mathrm{D}$ \\
\hline H8, H9 & 8 & $\mathrm{Rb} 11$ & $\mathrm{D}$ \\
\hline H6 & 8 & $\mathrm{Rb} 12$ & $\mathrm{D}$ \\
\hline $\mathrm{H} 10$ & 5 & $\mathrm{Rb} 23$ & $\mathrm{~F}$ \\
\hline H11 & 8 & $\mathrm{Rb} 24$ & $\mathrm{~F}$ \\
\hline \multicolumn{4}{|l|}{ Monkey isolates (2) } \\
\hline M1, M2 & 8 & $\mathrm{Rb} 1$ & A \\
\hline \multicolumn{4}{|l|}{ Reference strains and other isolates (9) } \\
\hline F. nucleatum ATCC 10953 & 8 & $\mathrm{Rb} 1$ & A \\
\hline F. nucleatum ATCC 25586 & 7 & $\mathrm{Rb} 20$ & $\mathrm{E}$ \\
\hline H. aphrophilus CDC & 6 & Rb19 & $\mathrm{D}$ \\
\hline \multicolumn{4}{|l|}{ A. actinomycetemcomitans ATCC 29522 , } \\
\hline ATCC 29523 and 43718 & 7 & $\mathrm{Rb} 26$ & $\mathrm{H}$ \\
\hline A. actinomycetemcomitans isolate PD1 & 8 & $\mathrm{Rb} 25$ & $\mathrm{G}$ \\
\hline A. actinomycetemcomitans isolate $\mathrm{PD} 2$ & 8 & $\mathrm{Rb} 27$ & $\mathrm{I}$ \\
\hline E. coli $\mathrm{CDC}$ & 10 & $\mathrm{Rb} 28$ & $\mathrm{~J}$ \\
\hline
\end{tabular}

patterns by one or more bands were considered distinct strains. All the F. nucleatum isolates from different sources and reference strains were classified in ten ribotype groups (A to J) (Table 1). Table 1 shows the hybridization patterns and ribotypes in all tested bacteria restricted with the EcoRI enzyme. All the $23 \mathrm{~F}$. nucleatum isolated from periodontal patients produced a range from three to 10 different hybridization patterns grouped in 12 ribotypes ( $\mathrm{Rb} 1, \mathrm{Rb} 2, \mathrm{Rb} 8, \mathrm{Rb}$, $\mathrm{Rb} 13, \mathrm{Rb} 14$ to $\mathrm{Rb} 18, \mathrm{Rb} 21$ and $\mathrm{Rb} 22)$. All nine F. nucleatum from AIDS-patients showed from seven to nine bands and they were clustered in six different ribotypes ( $\mathrm{Rb} 3$ to $\mathrm{Rb} 7$ and $\mathrm{Rb} 10)$. Of the eight $F$. nucleatum from healthy subjects, only two banding patterns (five and eight bands) were produced, then clustered in five different ribotypes (Rb8, Rb11, Rb12, Rb23, Rb24). Two F. nucleatum isolated from monkeys produced similar banding patterns (eight bands) than human isolates (Rb1). Interestingly, of nine HIV-patient isolates, six were clustered in group $\mathrm{C}$ and three isolates in the group D. It also was verified the similarities among $F$. nucleatum species isolated from AIDS-patients. In Fig. 2, it can be observed that F. nucleatum isolates from AIDS-patients displayed approximately $78 \%$ of similarity to A1, $\mathrm{A} 2, \mathrm{~A} 4, \mathrm{~A} 5, \mathrm{~A} 6$, and $\mathrm{A} 7$ isolates, and $88 \%$ to the $\mathrm{A} 3, \mathrm{~A} 8$ and $\mathrm{A} 9$ isolates. On the other hand, it was observed that two A. actinomycetemcomitans isolated from two periodontal patients (PD1, PD2) belonged to $\mathrm{G}(\mathrm{Rb} 25)$ and I (RB27) clusters, respectively, showing that they were different strains.

\section{DISCUSSION}

The significance of $F$. nucleatum in the development of the 


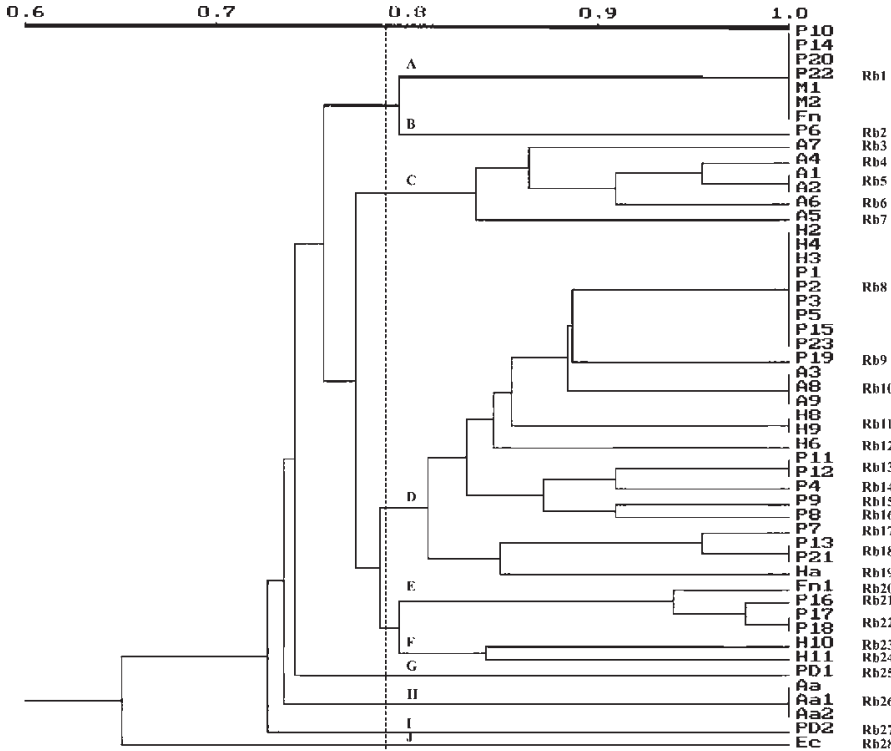

Fig. 2 - NTSYS dendrogram of genetic similarity for Fusobacterium nucleatum isolated from patients with different clinical conditions, analyzed by ribotyping. P: periodontal patient isolates; H: healthy individual isolates; A: AIDS patients isolates; M: monkey isolated; Ha: H. aphrophilus; Fn: F. nucleatum ATCC 10953; Fn1: F. nucleatum ATCC 25586; Aa, Aa1 and Aa2: A. actinomycetemcomitans reference strains; PD1 and PD2: A. actinomycetemcomitans clinical isolates; and Ec: E. coli CDC.

periodontal disease, as well as infections in other organs, has generated interest due to its pathogenic potential, its frequency in periodontal lesions, its synergism in mixed infections and its ability to form aggregates with other suspect pathogens in the periodontal disease $e^{7,12}$. Periodontal bacteria become pathogenic when $1 \%$ of the total organisms inhabit a dental biofilm sample, but their detection depends on the sensitivity and the specificity of the used method ${ }^{2}$. Then, an accurate identification is necessary, not only for taxonomic reasons, but also for the appropriate treatment of infections, since the susceptibility of different fusobacterial species to antibiotics, which varies widely ${ }^{10}$.

The ribotyping method by using the probe pKK3535 and the EcoRI endonuclease showed a high degree of specificity when hybridized with a panel of potential cross-hybridizing species. On the other hand, ribotyping distinguished among closely related species such as $H$. aphrophilus, a common bacterium in healthy subgingival sulci and $A$. actinomycetemcomitans, a periodontal pathogen. Since both species share approximately $40 \%$ of the DNA-DNA homology using wholecell probes, it can result in a high frequency of false-positive results with plaque samples or any other mixed population ${ }^{18}$.

In this study, ribotyping appear as an efficient method to distinguish F. nucleatum isolated from patients with different clinical conditions, i.e., periodontal patients, healthy subjects, and AIDS patients and monkeys. However, six and three AIDS isolates, respectively, were localized in $\mathrm{C}$ and $\mathrm{D}$ groups, and it is possible that these isolates present maybe any phenotypic or genotypic factor not detected here. In addition, all the $F$. nucleatum were recovered from AIDS-patients with periodontal disease and they were not identified at the subspecies level.
There are many difficulties in the search of the etiologic agents of destructive periodontal diseases in HIV-positive patients with AIDS, including technical problems and difficulties in determining the activity of the periodontal disease. On the other hand, level of complexity exists because strains within species can differ in virulence, as it has been suggested in F. nucleatum subspecies ${ }^{9}$. By using the EcoRI enzyme it was possible to distinguish 28 ribotypes grouped in 10 groups including F. nucleatum from different sources and reference strains (Table 1). However, nine F. nucleatum recovered from AIDS patients were grouped in six different ribotypes ( $\mathrm{Rb} 3$ to $\mathrm{Rb} 7$ and $\mathrm{Rb} 10)$. In conclusion, the results obtained here show that ribotyping can be used for differentiating strains from different clinical conditions. Because only nine $F$. nucleatum strains recovered from AIDS patients were studied, it is suggested the need of examining a larger number of strains to determine the role of F. nucleatum play in the periodontal disease in that patients.

\section{RESUMO}

\section{Diversidade genética de Fusobacterium nucleatum orais isolados de pacientes com diferentes condições clínicas}

Neste estudo foi avaliada a diversidade genética de 23 amostras de Fusobacterium nucleatum isoladas da cavidade bucal de 15 pacientes com doença periodontal, de oito cepas isoladas de sete indivíduos sadios, de nove isoladas de nove pacientes com AIDS e de duas isoladas de dois macacos Cebus apella. Pela ação da enzima EcoRI sobre o DNA bacteriano foram reconhecidos 28 ribotipos agrupados de A a J. Os isolados testados formaram 24 ribotipos os quais foram contidos nos grupos A, B, C, D, E e F, e as três cepas de referência e dois isolados clínicos de A. actinomycetemcomitans e E. coli CDC formaram quatro diferentes ribotipos contidos nos grupos G, H, I e J. Em adição, as nove cepas de $F$. nucleatum isoladas de pacientes com AIDS, seis pertenciam ao grupo $\mathrm{C}$ e três ao grupo D. Usando-se a ribotipagem foi possível distinguir $F$. nucleatum isolados de diferentes origens.

\section{ACKNOWLEDGMENTS}

Author thanks Dr. Leonard Mayer, Dr. Anne Whitney and Dr. Claudio Sacchi for their collaboration and critical suggestions. This study was partially supported by Fundação de Amparo à Pesquisa do Estado de São Paulo (FAPESP), Proc. Nº. 96/3115-7. MJA-C is partly supported by Conselho Nacional de Desenvolvimento Científico e Tecnológico (CNPq).

\section{REFERENCES}

1. AVILA-CAMPOS, M.J.; SACCHI, C.T.; WHITNEY, A.M.; STEIGERWALT, A.G. \& MAYER, L.W. - Arbitrarily primed polymerase chain reaction for identification and epidemiologic subtyping of oral isolates of Fusobacterium nucleatum. J. Periodont., 70: $1202-1208,1999$

2. BOLSTAD, A.I.; SKAUG, N. \& JENSEN, H.B. - Use of synthetic oligonucleotide DNA probes for the identification of different strains of Fusobacterium nucleatum. J. Periodont. Res., 26: 519-526, 1991.

3. BOLSTAD, A.I.; JENSEN, H.B. \& BAKKEN, V. - Taxonomy, biology and periodontal aspects of Fusobacterium nucleatum. Clin. Microbiol. Rev., 9: 55-71, 1996. 
4. BOUMA, C.L.; REIZER, J.; REIZER, A.; ROBRISH, A.S. \& THOMPSON, J. - 6phospho- $\alpha$-D-glucosidase from Fusobacterium mortiferum: cloning, expression, and assignment to family 4 of the glycosylhydrolases. J. Bact., 179: 4129-4137, 1997.

5. DZINK, J.L.; TANNER, A.C.R.; HAFFAJEE, A.D. \& SOCRANSKY, S.S. - Gramnegative species associated with destructive periodontal lesions. J. clin. Microbiol., 12: $648-659,1985$

6. EISENSTEIN, B.I. - New molecular techniques for microbial epidemiology and the diagnosis of infectious diseases. J. infect. Dis., 161: 595-602, 1990.

7. FEUILLE, F.; EBERSOLE, J.L.; KESAVALU, L; STEPFEN, M.J. \& HOLT, S.C. - Mixed infection with Porphyromonas gingivalis and Fusobacterium nucleatum in a murine lesion model: potential synergistic effects on virulence. Infect. Immun., 64: 20942100,1996

8. GAETTI-JARDIM, E.; ZELANTE, F. \& AVILA-CAMPOS, M.J. - Oral species of Fusobacterium from human and environmental samples. J. Dent., 24: 345-348, 1996.

9. GENCO, R.J. \& LOOS, B.G. - The use of genomic DNA fingerprinting in studies of the epidemiology of bacteria in periodontitis. J. clin. Periodont., 18: 396-405, 1991.

10. GEORGE, W.L.; KIRBY, B.D.; SUTTER, V.L.; CITRON, V.L. \& FINEGOLD, S.M. Gram-negative anaerobic bacilli: their role in infection and patterns of susceptibility to antimicrobial agents. II. Litlle known Fusobacterium species and miscellaneous genera. Rev. infect. Dis., 3: 599-626, 1981.

11. GEORGE, K.S.; REYNOLDS, M.A. \& FALKLER Jr., W.A. - Arbitrarily primed polymerase chain reaction fingerprinting and clonal analysis of oral Fusobacterium nucleatum isolates. Oral Microbiol. Immunol., 12: 219-226, 1997.

12. KOLENBRANDER, P.E. \& LONDON, J. - Adhere today, here, tomorrow: oral bacterial adherence. J. Bact., 175: 3247-3252, 1993.
13. KONONEN, E.; ASIKAINEN, S.; SAARELA, M.; KARJALAINEN, J. \& JOUSIMIESSOMER, H. - The oral gram-negative anaerobic microflora in young children longitudinal changes from edentulous to dentate mouth. Oral Microbiol. Immunol., 9: $136-141,1994$.

14. MÖLLER, A.J. - Microbiological examination of root canals and periapical tissues of human teeth. Methodological studies. Odont. Tidsk., 74 (suppl. 5): 1-380, 1966.

15. MOORE, W.E.C. \& HOLDEMAN, L.V. - Genus II: Fusobacterium,. In: BUCHANAN, R.E. \& GIBBONS, N.J., ed. Bergey's manual of determinative bacteriology. 8 . ed. Baltimore, Williams \& Wilkins, 1974. p. 404.

16. MORRIS, M.L.; ANDREWS, R.H. \& ROGERS, A.H. - Investigations of the taxonomy and systematic of Fusobacterium nucleatum using allozyme electrophoresis. Int. J. syst. Bact., 47: 103-110, 1997.

17. ROBERTS, M.; MONCLA, B. \& KENNY, G.E. - Chromosomal DNA probes for the identification of Bacteroides species. J. gen. Microbiol., 133: 1423-1430, 1987.

18. STRZEMPKO, M.M.; SIMON, S.L.; FRENCH, C.K. et al. - A cross-reactivity study of whole genomic DNA probes for Haemophilus actinomycetemcomitans, Bacteroides intermedius and Bacteroides gingivalis. J. Dent. Res., 66: 1543-1546, 1987.

19. SUTTER, V.L.; CITRON, D.M.; FINEGOLD, S.M. \& BRICKNELL, K. - Wadsworth anaerobic Bacteriology manual. 2. ed. St. Louis, Mosby, 1980.

Received: 14 July 2005

Accepted: 8 December 2005 